\title{
Carbon Storage in Agroecosystems: A Case Study of the Cocoa Based Agroforestry in Ogbese Forest Reserve, Ekiti State, Nigeria
}

\author{
David Oke, Ayodeji Olatiilu \\ Department of Forestry and Wood Technology, Federal University of Technology, Akure, Nigeria. \\ Email: davoke2003@yahoo.com
}

Received June $8^{\text {th }}$, 2011; revised August $19^{\text {th }}, 2011$; accepted September $18^{\text {th }}, 2011$.

\begin{abstract}
Large areas of the indigenous tropical forests in the southwestern part of Nigeria are being converted into agricultural lands and this has been reported to have serious implications for biodiversity and the environment. Cocoa based agroforestry is one of the common agricultural practices in this region and comparative information on the carbon storage capacity of the cocoa agroforests is generally lacking. In this study the above-ground carbon storage and partitioning in a protected primary forest were evaluated and compared with those of the two categories of cocoa agroforests (sparse and dense) identified in the area. Above-ground biomass accumulation and carbon stock varied significantly with land use type, with the primary rainforest having the highest values and sparse cocoa agroforests having the lowest. A reduction in above-ground carbon stock of $89.82 \%$ and $71.20 \%$ was observed 10 years after conversion of tropical rainforest to sparse and dense cocoa agroforests respectively.
\end{abstract}

Keywords: Carbon Sequestration, Cocoa, Agroforestry, Forest Conversion, Global Climate Change

\section{Introduction}

Carbon dioxide $\left(\mathrm{CO}_{2}\right)$ is one of the greenhouse gases and a primary agent of global warming. It constitutes $72 \%$ of the total anthropogenic greenhouse gases, causing between $9 \%-26 \%$ of the greenhouse effect [1]. Reference [2] reported that the amount of carbon dioxide in the atmosphere has increased from $280 \mathrm{ppm}$ in the preindustrial era (1750) to $379 \mathrm{ppm}$ in 2005, and is increasing by 1.5 ppm per year. Dramatic rise of $\mathrm{CO}_{2}$ concentration is attributed largely to human activities. Over the last 20 years, majority of the emission is attributed to burning of fossil fuel, while $10 \%-30 \%$ is attributed to land use change and deforestation [3].

Article 4 of the United Nations Framework Convention on Climate Change (UNFCCC) requires preventing and minimizing climate change by "limiting anthropogenic emissions of greenhouse and protecting and enhancing greenhouse gas sinks and reservoirs" [4]. Forest ecosystem plays very important role in the global carbon cycle. It stores about $80 \%$ of all above-ground and $40 \%$ of all below-ground terrestrial organic carbon [3]. However, the state of tropical forests has continued to deteriorate.
Reference [5] reported that the protection of existing forests, regeneration of degraded forests and raising of forest plantations have been contributing to enhanced carbon stock in India. However, the data available on carbon sequestration i.e. net woody biomass accumulation in trees for long term storage in tropical forests are extremely limited and incomplete. Thus, the improved quantification of carbon pools and fluxes in tropical forest ecosystems is important for understanding the contribution of these forests to net carbon emissions and their potential for carbon sequestration [6].

Agroecosystems play a central role in the global carbon cycle and contain approximately $12 \%$ of the world terrestrial carbon [7]. From the perspective of climate change and the global carbon cycle, agroforestry is attractive because the tree component has the capacity to fix and store carbon from the atmosphere for many years. The amount of carbon sequestered largely depends on the agroforestry system put in place, the structure and function of which are, to a great extent, determined by environmental and socio-economic factors. Other factors influencing carbon storage in agroforestry systems include tree species and system management. 
Cocoa agroforests are a common farming system in the humid zone of West and Central Africa, in which forest trees provide shade and other environmental services as well as marketable products [8]. Traditionally, small holder cocoa farmers establish their farms by removing the forest under-storey and thinning the forest canopy so that Cocoa seedlings can grow into productive trees, as for example in Cameroon [9]. Many authors [10-14] have described the physiological, environmental and economic values of shade trees in cocoa growing systems. They cited benefits such as shade to cocoa, soil fertility maintenance, biodiversity conservation, protection against drought, bush fires and insect attacks as well as additional income through sales of timber species, fuel wood, and non-wood forest products.

The trees in cocoa agroforests can store carbon in their shoots and roots, while performing the aforementioned roles thereby reducing the greenhouse effect. This study was carried out to assess and compare carbon storage in cocoa based agroforestry systems and a relatively untouched rainforest in Ogbese Forest Reserve, Ekiti State, Nigeria.

\section{Materials and Method}

\subsection{The Study Area}

The study was carried out in Ogbese Forest Reserve in Ekiti State, (Lat. $7^{\circ} 31^{\prime}$ and $7^{\circ} 49^{\prime} \mathrm{N}$ and Lat. $5^{\circ} 7^{\prime}$ and $\left.5^{\circ} 27^{\prime} \mathrm{E}\right)$. The area lies entirely within the pre-Cambrian Basement Complex rock group which underlies much of Nigeria. The elevation reaches $600 \mathrm{~m}$ above the sea level and is situated entirely within the upper Ogbese basin.

The area experiences a tropical climate with distinct wet and dry seasons. The rainy season lasts for 9 months annually between March and November while the dry season lasts for 3 months between December and February. The annual mean total rainfall is $1367 \mathrm{~mm}$; the average number of the rainy days is 112 per annum [15].

Temperature is almost uniform throughout the year with very little deviation from the mean annual of $27^{\circ} \mathrm{C}$. The mean annual relative humidity varies between $50 \%$ and $95 \%$ and is highest in the rainy season months.

\subsection{Sampling}

Ten-year-old cocoa farms established in, and around Ogbese Forest Reserve, Ekiti State were visited to select appropriate sites for this study. Based on the number of shade trees (non cocoa trees) per unit area, the farms were classified into dense and sparse mixtures. Four farms under each category were selected for detailed biomass measurement. Sample plots were also demarcated within the natural forest whose canopy had not been disturbed by the activity of a cocoa farmer or where there is little or no evidence of timber extraction. One plot ( $25 \mathrm{~m} \times 25 \mathrm{~m}$ in size) was located in each of the selected cocoa farms and four at random locations within the natural forest.

\subsection{Biomass Estimation}

All cocoa trees in each plot were measured for stem diameter distribution. Two mean cocoa trees with dbh nearest to the mean dbh were located in each of the plots within cocoa farms and selected for destructive sampling after their heights, diameters at the base, at the middle and at the top have been measured and recorded. The biomass measurements were based on the biomass subsampling method outlined by [16]. The two mean cocoa trees were felled at the ground level. Each felled tree was sorted into the three main components; bole, branches and foliage and each component was cut into small pieces for easy weight measurement. Samples were taken to the laboratory for dry weight determination. As recommended by [16], stem material removed in saw cuts were also considered as $0.5 \%$ of the stem biomass. Volumes of the two (2) mean cocoa trees in each sample plot were calculated using the Newton's formula by [17].

Diameter and height measurements of all the non cocoa trees in each plot were also taken and their volumes calculated using the Newton's formula by [17]. However, due to the variety and size of non cocoa tree species encountered and the difficulty in getting the cocoa farmers to allow felling of such shade trees because of the fear of massive destruction of non target cocoa trees that could accompany such an exercise, the above ground biomass of non cocoa trees in the plots was estimated indirectly from the volume data using the formula:

$$
\text { Aboveground biomass }=\mathrm{VOB} \times \mathrm{WD} \times \mathrm{BEF}
$$

where:

$\mathrm{WD}=$ volume-weighted average wood density

$\mathrm{BEF}=$ biomass expansion factor (ratio of aboveground oven-dry biomass of trees to the oven-dry biomass of inventoried volume). WD was estimated as described by [18].

The wood density values (Table 1) were obtained from [18]. The biomasses were added for each plot and expanded to biomass in tonnes per hectare.

\subsection{Carbon Estimation}

The carbon concentration of different tree parts is rarely measured directly, but generally assumed to be $50 \%$ of dry weight [19]. Hence in this study, the aboveground carbon stock was calculated by assuming that the carbon content is $50 \%$ of the total aboveground biomass [5, 
20-24].

\subsection{Data Analysis}

Correlation analysis was carried out to examine relationships between some paired growth parameters. Carbon storage values estimated for sparse mixtures, dense mixtures and the natural forest were compared using one way Analysis of Variance (ANOVA). The three (3) stands formed the treatments while the four (4) plots sampled in each of the stands formed the replicates. The test was conducted for significant difference in the carbon stock for the three different stands. Mean separation was carried out with Fisher's Least Significant Difference (LSD) where significant differences occur $(\mathrm{P}<$ 0.05).

\section{Results}

\subsection{Distribution of Cocoa and Shade Tree Species}

Seventy six shade trees were encountered in the 1 ha of dense cocoa agroforests and these were made up of 9 different species in 5 families while 40 shade trees encountered in sparse cocoa agroforests and these were distributed in 5 species and 4 families. In the one hectare of natural forest surveyed, 166 trees were encountered and these were distributed in 15 species and 7 families (Table 2). Ficus mucuso was found to be the most frequently occurring species with 41, 22 and 18 trees in the natural forest, dense cocoa agroforest and sparse cocoa agroforest respectively. This was followed by Antiaris africana occurring 25, 14 and 10 times respectively. The highest number of trees (336) were encountered in the sparse cocoa agroforests and these were made up of 296 cocoa trees and 40 shade trees (Table 3). In the dense mixture 308 trees were recorded made up of 232 cocoa and 76 shade trees. There were 166 trees in the natural forest which contained no cocoa tree.

The summary of the cocoa tree growth data presented in Table 4 for Sparse and Dense Cocoa Agroforests shows that Mean Dbh and Mean Height respectively

Table 1. Scientific names, family and wood density (as obtained from [18]) of the non cocoa tree species encountered in the study area.

\begin{tabular}{|c|c|c|}
\hline Species & Family & Wood Density $\left(\mathrm{t} / \mathrm{m}^{3}\right)$ \\
\hline Afzelia Africana Kuntze & Leguminoseae & 0.63 \\
\hline Triplochiton scleroxylon Schumann & Sterculiaceae & 0.32 \\
\hline Ficus mucuso Welw ex. Ficalho & Moraceae & 0.39 \\
\hline Pterygota macrocarpa K. Schum & Sterculiaceae & 0.52 \\
\hline Terminalia superb Engl. \& Diels & Combretaceae & 0.45 \\
\hline Antiaris Africana Engl. & Moraceae & 0.37 \\
\hline Sterculia oblonga Mast. & Sterculiaceae & 0.61 \\
\hline Alstonia boonei De Wild & Apocynaceae & 0.33 \\
\hline Entandrophragma utile Sprague & Meliaceae & 0.53 \\
\hline Celtis zenkeri Engl & Ulmaceae & 0.59 \\
\hline Daniella oliveri Rolfe & Caesalpiniaceae & 0.40 \\
\hline Terminalia ivorensis A. Chev & Combretaceae & 0.45 \\
\hline Holoptelia grandis Hutch (Mildbr) & Ulmaceae & 0.59 \\
\hline Nesogordonia papaverifera A.Chev. & Sterculiaceae & 0.65 \\
\hline Khaya ivorensis A.Chev. & Meliaceae & 0.44 \\
\hline Pycnanthus angolensis Welw & Myristicaceae & 0.40 \\
\hline Daniella ogea Harms & Leguminoseae & 0.40 \\
\hline Gossweilerodendron balsamiferum Harms & Leguminoseae & 0.40 \\
\hline
\end{tabular}


Table 2. Diversity of non cocoa/shade tree species in 1 ha of sampled ecosystems in Ogbese Forest Reserve.

\begin{tabular}{|c|c|c|c|c|c|}
\hline \multicolumn{2}{|c|}{ Natural Forest } & \multicolumn{2}{|c|}{ Dense Cocoa Agroforest } & \multicolumn{2}{|c|}{ Sparse Cocoa Agroforest } \\
\hline Species & Freq. & Species & Freq. & & Freq. \\
\hline Afzelia africana & 10 & Triplochiton scleroxylon & 9 & Ficus muсuso & 18 \\
\hline Triplochiton scleroxylon & 12 & Ficus mucuso & 22 & Antiaris africana & 10 \\
\hline Ficus mucuso & 41 & Antiaris Africana & 14 & Sterculia oblonga & 4 \\
\hline Pterygota macrocarpa & 11 & Pterygota macrocarpa & 3 & Terminalia ivorensis & 6 \\
\hline Terminalia superba & 13 & Entandrophragma utile & 9 & Alstonia boonei & 2 \\
\hline Antiaris africana & 25 & Afzelia Africana & 4 & & \\
\hline Sterculia oblonga & 10 & Daniella oliveri & 5 & & \\
\hline Alstonia boonei & 7 & Sterculia oblonga & 7 & & \\
\hline Entandrophragma utile & 12 & Terminalia ivorensis & 3 & & \\
\hline Celtis zenkeri & 3 & & & & \\
\hline Daniella oliveri & 3 & & & & \\
\hline Terminalia ivorensis & 6 & & & & \\
\hline Holoptelia grandis & 4 & & & & \\
\hline Nesogordonia papaverifera & 2 & & & & \\
\hline Khaya ivorensis & 7 & & & & \\
\hline Total & 166 & Total & 76 & Total & 40 \\
\hline
\end{tabular}

Table 3. Distribution of cocoa and non-cocoa trees in 1 ha of sampled ecosystems in Ogbese Forest Reserve.

\begin{tabular}{|c|c|c|c|}
\hline Stand Type & No of Cocoa Trees/ha & No of Shade Trees/ha & Total no of trees/ha \\
\hline Sparse Cocoa Agroforest & 296 & 40 & 336 \\
\hline Dense Cocoa Agroforest & 232 & 76 & 308 \\
\hline Natural Forest & - & 166 & 166 \\
\hline
\end{tabular}

Table 4. Distribution of aboveground biomass in the cocoa trees of ten-year-old cocoa agroforests in Ogbese Forest Reserve.

\begin{tabular}{cccccc}
\hline \multirow{2}{*}{ Stand Type } & Tree Components & Biomass (t/ha) & Proportion (\%) & Carbon (t/ha) & Proportion (\%) \\
\hline Sparse Cocoa Agroforest & Stem & 5.40 & 83.98 & 2.70 & 83.85 \\
& Branches & 0.81 & 12.60 & 0.41 & 12.73 \\
& Foliage & 0.22 & 3.42 & 0.11 & 3.42 \\
& Total Aboveground Biomass & 6.43 & 100.00 & 3.22 & 100.00 \\
Dense Cocoa Agroforest & Stem & 4.80 & 87.11 & 2.40 & 86.96 \\
& Branches & 0.58 & 10.53 & 0.29 & 10.51 \\
& Foliage & 0.13 & 2.40 & 0.07 & 2.54 \\
& Total Aboveground Biomass & 5.51 & 100.00 & 2.76 & 100.00 \\
\hline
\end{tabular}


were both higher in Dense Cocoa Agroforest $(11.70 \mathrm{~cm}$ and $6.79 \mathrm{~m})$ than in the sparse mixture $(11.30 \mathrm{~cm}$ and $6.66 \mathrm{~m}$ ), other parameters i.e. Basal area/ha and Volume/ ha were also higher in the Dense stand than in the Sparse mixtures. The Basal area/ha was $2.20 \mathrm{~m}^{2}$ and $2.49 \mathrm{~m}^{2}$ while volume/ha was $10.46 \mathrm{~m}^{3}$ and $12.47 \mathrm{~m}^{3}$ in the Sparse and Dense Cocoa Agroforests respectively. Similarly, the shade trees in Dense Cocoa Agroforests were higher in all the growth parameters than those in the Sparse stand as many large trees had been removed from the Sparse stand while these trees were still providing much shade in the Dense Cocoa Agroforest. Mean Dbh and Mean Height of shade trees were $43.60 \mathrm{~cm}$ and $21.82 \mathrm{~m}$ in the Dense stand compared to $38.30 \mathrm{~cm}$ and 21.15 respectively in the Sparse stand. Basal area and volume of shade trees per ha were $14.92 \mathrm{~m}^{2}$ and 192.65 $\mathrm{m}^{3}$ respectively in the dense stand while $4.46 \mathrm{~m}^{2}$ and $50.80 \mathrm{~m}^{3}$ were recorded for the sparse.

\subsection{Aboveground Biomass Accumulation and Partitioning}

The partitioning of biomass in the cocoa trees is presented in Table 5. A total above ground biomass of 6.43 $\mathrm{t} / \mathrm{ha}$ was obtained for cocoa trees in the sparse cocoa agroforest. Stem biomass accounted for an average of 83.98\% (5.40 t/ha) while branch and foliage biomasses accounted for an average of $12.60 \%(0.81 \mathrm{t} / \mathrm{ha})$ and $3.42 \%$ (0.22 t/ha) respectively. In the Dense Cocoa Agroforests, the total above ground biomass of cocoa trees was $5.51 \mathrm{t} / \mathrm{ha}$. Stem biomass was found to be 87.11\% (4.80 t/ha) while branch and foliage biomasses were $10.53 \%$ (0.58 t/ha) and $2.40 \%$ (0.13 t/ha) respectively. The highest total above ground biomass (333.34 t/ha) was observed in the natural forest while the least was in the sparse cocoa agroforest (Table 6). Only $5.73 \%$ of the $96.01 \mathrm{t} / \mathrm{ha}$ of biomass observed in the dense cocoa agroforests was accounted for by the cocoa trees. The cocoa trees also accounted for $18.97 \%$ of the aboveground biomass in the sparse cocoa agroforests.

\subsection{Carbon Storage in the Cocoa Agroforests and the Natural Forest}

Figure 1 shows the aboveground carbon storage in the three types of ecosystems considered. Statistical analysis showed that Carbon storage/ha varied significantly among Sparse Cocoa Agroforest, Dense Cocoa Agroforest and the Natural Forest. The highest value of 184.99 t/ha was obtained for the natural forest while the least was in the sparse cocoa agroforest.

\section{Discussion}

Numerically, there were more trees in the sparse cocoa agroforests than in the other two ecosystems but a high proportion of these were cocoa trees which were smaller in size compared to the non cocoa trees. The summary of the Cocoa tree growth data shows that the Dense Cocoa Agroforest had higher Mean Dbh and Mean Height than the Sparse Cocoa Agroforest and there were more natural or shade trees in the Dense mixtures than in the sparse mixtures. The lower growth parameters (Mean Dbh, Mean Height, Mean Basal Area and Mean Volume) in the sparse mixture may be attributed to the closer spacing of the cocoa trees as there were more cocoa trees per hectare than in the Dense mixtures. The minimum and maximum Dbh recorded for cocoa trees in the Dense Cocoa agroforest were also higher than those of the Sparse.

Table 5. Growth of cocoa and non cocoa trees in the cocoa agroforests and natural forest of Ogbese Forest Reserve.

\begin{tabular}{|c|c|c|c|c|c|}
\hline & \multicolumn{2}{|c|}{ Sparse Cocoa Agroforest } & \multicolumn{2}{|c|}{ Dense Cocoa Agroforest } & \multirow{2}{*}{$\begin{array}{c}\text { Natural Forest } \\
\text { Non-Cocoa }\end{array}$} \\
\hline & Cocoa & Non-Cocoa & Cocoa & Non-Cocoa & \\
\hline MDbh (cm) & $11.30 \pm 0.00$ & $38.30 \pm 0.12$ & $11.70 \pm 0.00$ & $43.60 \pm 0.01$ & $49.43 \pm 0.08$ \\
\hline MHt (m) & $6.66 \pm 0.51$ & $21.15 \pm 1.21$ & $6.79 \pm 0.12$ & $21.82 \pm 0.86$ & $24.76 \pm 1.87$ \\
\hline No./ha & $296.00 \pm 1.29$ & $40.00 \pm 0.58$ & $232.00 \pm 0.58$ & $96.00 \pm 0.82$ & $188.00 \pm 1.71$ \\
\hline Vol/ha $\left(\mathbf{m}^{3}\right)$ & $10.46 \pm 0.02$ & $50.80 \pm 0.49$ & $12.47 \pm 0.00$ & $192.65 \pm 0.24$ & $673.88 \pm 1.04$ \\
\hline Ba/ha $\left(\mathbf{m}^{2}\right)$ & $2.20 \pm 0.00$ & $4.46 \pm 0.08$ & $2.49 \pm 0.00$ & $14.92 \pm 0.01$ & $39.96 \pm 0.06$ \\
\hline & \multicolumn{2}{|c|}{ Sparse Cocoa Agroforest } & \multicolumn{2}{|c|}{ Dense Cocoa Agroforest } & Non-Cocoa \\
\hline Cocoa & \multicolumn{2}{|c|}{6.44} & \multicolumn{2}{|l|}{5.51} & 0 \\
\hline Shade tree & \multicolumn{2}{|c|}{27.50} & \multicolumn{2}{|l|}{90.50} & 333.34 \\
\hline Total & \multicolumn{2}{|c|}{33.94} & \multicolumn{2}{|l|}{96.01} & 333.34 \\
\hline
\end{tabular}




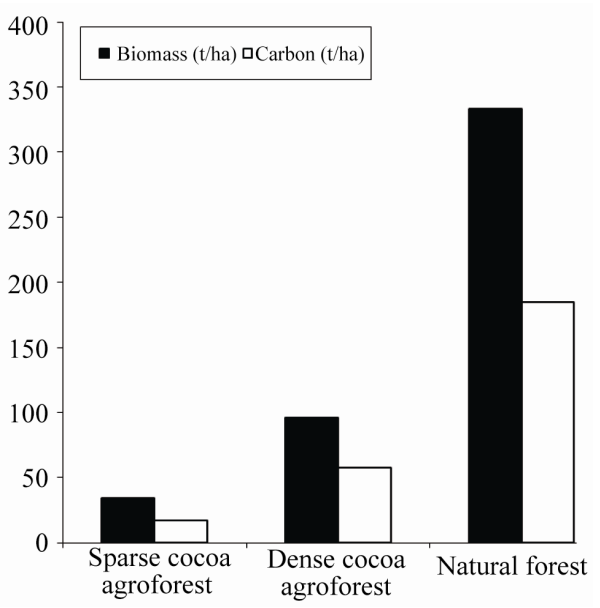

Figure 1. Biomass and carbon storage/ha in the study area.

Growth parameters such as MDbh, MHt, Volume and Basal area of non cocoa trees were all higher in the Dense Cocoa Agroforest than in the Sparse mixture. This may be attributed to the removal of many large shade trees in the Sparse mixture to open the canopy for the establishment of Cocoa plantation.

The mean Aboveground Biomass (AGB) for Cocoa trees in the Dense Cocoa Agroforest was higher than that of the Sparse mixture. This is in agreement with the reports of [25] on the effect of shade tree in an 8-year-old cocoa Agroforestry system in which they concluded that Cocoa Biomass was higher under shade. The proportion of AGB concentrated in the stem was also found to be higher in Dense Cocoa Agroforest than in the Sparse. This is due to the fact that more AGB were in branches and foliage of Sparse Cocoa Agroforest than in the Dense Cocoa Agroforest. Cocoa trees in the Dense Cocoa Agroforests were found to have more stem Bio- masses and less branch and foliage Biomasses than those in the Sparse Cocoa Agroforest.

The aboveground Biomass of shade trees in the Dense mixture was higher than in the Sparse due to the number and size of the trees found in the stands. Total AGB/ha was highest in the natural forest followed by the Dense and the Sparse mixtures in that order for the same reason. TAGB was more than three times higher in the natural forest than in the Dense Cocoa agroforest. Reference [26] reported that the values for natural forest could be about 3 - 4 times higher. The total aboveground Biomass obtained in the natural forest is comparable to $444.70 \mathrm{t} / \mathrm{ha}$ obtained by [27] in Indonesia.

The carbon storage value of $57.55 \mathrm{t} / \mathrm{ha}$ observed for ten year old Dense Cocoa Agroforest in this study was less than that obtained in Mango Agroforestry system (121.1 $\mathrm{t} / \mathrm{ha}$ ) in Indonesia [28] and higher than that of five-year-old Cocoa-gliricidia (38.86 t/ha) [29].
In the natural forest, the large trees contributed more than $45 \%$ to the total AGB. The greater contribution of large trees to AGB in natural forest is in agreement with the findings of previous workers [30-32] who reported up to $50 \%$ contribution to AGB by large trees (of Dbh $>0.7$ $\mathrm{m})$. A higher proportion of AGB in the large trees in the natural forest indicates that such trees play important role in Carbon storage; notwithstanding, small trees (of Dbh < $0.6 \mathrm{~m}$ ) enhance future Carbon storage as they are high in Carbon storage potential.

\section{Conclusions}

The study shows that AGB of Cocoa increases with increase in density of shade trees. It was also discovered that growth characteristics of Cocoa are higher under shade.

It has been shown clearly by the result of this study that Cocoa Agroforests store substantial Carbon as seen in the Dense Cocoa Agroforest. From the perspective of climate change, Cocoa Agroforests are attractive; not only that the Cocoa component stores Carbon in addition to the natural trees but also that the system potentially slows down deforestation by reducing the need to completely clear forestland for agriculture. This will be more acceptable to rural farmers than complete afforestation. Therefore Cocoa Agroforest is recommended as one of the options in combating climate change.

\section{REFERENCES}

[1] J. T. Kiehl and K. E. Trenberth, "Earth’s Annual Global Mean Energy Budget,” Bulletin of the American Meteorological Society, Vol. 78, No. 2, 1997, pp. 197-208. doi:10.1175/1520-0477(1997)078<0197:EAGMEB>2.0.C $\underline{\mathrm{O} ; 2}$

[2] IPCC, "Climate Change 2007: The Physical Science Basis, Summary for Policymakers," The IPCC 4th Assessment Report (IPCC AR4), Intergovernmental Panel on Climate Change, 2007.

[3] IPCC, "Climate Change 2001: Impacts, Adaptation, and Vulnerability," Contribution of Working Group II to the 3rd Assessment Report of the Intergovernmental Panel on Climate Change, Cambridge University Press, Cambridge and New York, 2001.

[4] United Nations, "United Nations Framework Convention on Climate Change (UNFCC),” 2006.

http://unfcc.int/resource/docs/convkp/conveng.pdf

[5] N. H. Ravindranath, B. S. Somashekhar and M. Gadgil, "Carbon Flow in India Forests," Climatic Change, Vol. 35, 1997, pp. 297-320. doi:10.1023/A:1005303405404

[6] A. Chhabra and V. K. Dadhwal, "Assessment of Major Pools and Fluxes of Carbon in Indian Forests," Climate Change, Vol. 64, No. 3, 2004, pp. 341-360. doi:10.1023/B:CLIM.0000025740.50082.e7 
[7] R. K. Dixon, “Agroforestry Systems: Sources of Sinks of Greenhouse Gases?” Agroforestry Systems, Vol. 31, No. 2, 1995, pp. 99-116. doi:10.1007/BF00711719

[8] D. O. Oke and K. A. Odebiyi, "Traditional Cocoa-Based Agroforestry and Forest Species Conservation in Ondo State, Nigeria," Agriculture, Ecosystems and Environment, Vol. 122, No. 3, 2007, pp. 305-311. doi:10.1016/j.agee.2007.01.022

[9] B. Duguma, J. Gockowski and J. Bakala, "Small Holder Cacao (Theobroma Cacao Linn). Cultivation in Agroforestry Systems of West and Central Africa: Challenges and Opportunities,” Agroforestry Systems, Vol. 51, No. 3, 2001, pp. 177-188. doi:10.1023/A:1010747224249

[10] P. T. Alvim, "Ecological and Physiological Determinants of Cocoa Yield," Proceedings of the 5th International Cocoa Research Conference, Ibadan, 1-9 September 1979, pp. 25-38.

[11] W. V. Hutcheon, "Physociological Aspects of Cocoa Agronomy," Proceedings of the 5th International Cocoa Research Conference, Ibadan, 1-9 September 1979, pp 39-48.

[12] Y. A. Olaniran, "Focus on Light Climate in Cocoa Production," Proceedings of 5th International Cocoa Research Conference, Ibadan, 1-9 September 1979, pp. 271-277

[13] L. Zapfack, S. Engwald, B. Sonke, G. Achoundong and B. A. Madong, "The Impact of Land Use Conversion on Plant Biodiversity in the Forest Zone of Cameroon,” Biodiversity and Conservation, Vol. 11 No. 11, 2002, pp. 2047-2061. doi:10.1023/A:1020861925294

[14] G. Schroth, A. B. Gustavo, C. A. da Fonseca, C. Harvey, H. L. Gascon, A. M. Vasconcelos and N. Izac, "Agroforestry and Biodiversity Conservation in Tropical Landscapes,” Island Press, Washington DC, 2004, p. 523.

[15] J. S. Oguntoyinbo, "Climate, Precipitation and Radiation,” In: K. M. Babour, et al., Eds., Nigeria in Maps, Hodder and Stoughton, London.

[16] P. Snowdown, J. Raison, H. Keith, P. Ritson, P. Grierson, M. Adams, K. Montagu, H. Bi, W. Burrows and D. Eamus, "Protocol for Sampling Tree and Stand Biomass," National Carbon Accounting System, Technical Report No. 31, March 2002.

[17] B. C. Husch, C. I. Miller and T. W. Beens, "Forest Mensuration,” 3rd Edition, Wiley, New York, 1982, p. 402.

[18] S. Brown, "Estimating Biomass and Biomass Change of Tropical Forests,” FAO. Forest Paper 134, A Forest Resources Assessment Publication, Rome, 1997, p. 55.

[19] J. Stephens, "Growing Interest in Carbon Capture and Storage (CCS) for Climate Change Mitigation,” Sustainability: Science, Practice and Policy, Vol. 2, No. 2, 2006, pp. 4-13.

[20] S. Brown and A. E. Lugo, "The Storage and Production of Organic Matter in Tropical Forests and Their Role in the Global Carbon Cycle,” Biotropica, Vol. 14, 1982, pp. 161-187. doi:10.2307/2388024

[21] M. G. R. Cannell and R. Milne, "Carbon Pools and Se- questration in Forest Ecosystems in Britain” Forestry, Vol. 68, No. 4, 1995, pp. 361-378. doi:10.1093/forestry/68.4.361

[22] R. K. Dixon, S. Brown, R. A. Houghton, A. M. Solomon, M. C. Trexler and J. Wisniewski, "Carbon Pools and Flux of Global Forest Ecosystems,” Science, Vol. 263, No. 3654, 1994, pp. 185-190. doi:10.1126/science.263.5144.185

[23] D. D. Richter , D. Markewitz, J. K. Dunsomb, C. G. Wells, A. Stuanes, H. L. Allen, B. Ureego, K. Harrison and G. Bonani, "Carbon Cycling in a Loblobby Pine Forest: Implication for the Missing Carbon Sink and for the Concept of Soil,” In: W. W. McFee and J. L. Kelly, Eds., Carbon Forms and Function in Forest Soils, Soil Science Society of America, Madison, 1995, pp. 223-251.

[24] P. Schroeder, "Carbon Storage Potential of Short Rotation Tropical Tree Plantations,” Forest Ecology and Management, Vol. 50, No. 1-2, 1992, pp. 31-41. doi:10.1016/0378-1127(92)90312-W

[25] M. E. Isaac, V. R. Timmer and S. J. Quashie-Sam, "Shade Tree Effects in an 8-Year-Old Cocoa Agroforestry System: Biomass and Nutrient Diagnosis of Theobroma Cacao by Vector Analysis," Nutrient Cycling in Agroecosystems, Vol. 78, No. 2, 2007, pp. 155-165. doi:10.1007/s10705-006-9081-3

[26] I. E. Henson, “Comparative Ecophysiology of Oil Palm and Tropical Rain Forest,” In: S. Gurmit, K. H. Lim, L. Teo and K. Lee, Eds., Oil Palm and the Environment, Malaysian Oil Palm Growers' Council, Kuala Lumpur, 1999, pp. 9-39.

[27] S. Naimatu, "Estimating Above-Ground Biomass and Carbon Stock of Forest Cover Using Multispectral Satellite Images in Lore Lindu National Park-Central Sulawesi,” Graduate School, Bogor Agricultural University, Bogor, 2007.

[28] G. Kirsfianti, C. W. Yuliana and L. Mega, "Potential of Agroforestry and Plantation Systems in Indonesia for Carbon Stocks: An Economic Perspective,” Working Paper CC14, ACIAR Project ASEM 2002/066.

[29] G. L. Smiley and J. Kroschel, "Temporal Change in Carbon Stocks of Cocoa-Gliricidia Agroforests in Central Sulawesi, Indonesia,” Agroforestry Systems, Vol. 73, No. 3, 2008, pp. 219-231. doi:10.1007/s10457-008-9144-3

[30] S. Brown, "Tropical Forests and the Global Carbon Cycle: Estimating State and Change in Biomass Density,” In: M. Apps and D. Price, Eds., Forest Ecosystems, Forest Management and the Global Carbon Cycle, NATO ASI Series, Springer-Verlag, Berlin, 1996, pp. 135-144.

[31] I. F. Brown, L. A. Martinelli, W. W. Thomas, M. Z. Moreira, C. A. C. Ferreira and R. A. Victoria, "Uncertainty in the Biomass of Amazonian Forests-An Example from Rondonia, Brazil,” Forest Ecology and Management, Vol. 75, No. 1-3, 1995, pp. 175-189. doi:10.1016/0378-1127(94)03512-U

[32] S. Brown and A. E. Lugo, "Aboveground Biomass Estimates for Tropical Moist Forests of the Brazilian Amazon,” Interciencia, Vol. 17, 1992, pp. 8-18. 